\title{
EFEKTIVITAS HUKUM TERHADAP REALISASI SISTEM JARINGAN SUMBER DAYA AIR PADA RENCANA TATA RUANG WILAYAH KOTA TANJUNGPINANG PERIODE $2014-2017$
}

\author{
Dzulkarnain* \\ Universitas Maritim Raja Ali Haji, Tanjungpinang
}

\begin{abstract}
Development is a conscious effort made by humans to achieve a better life. The essence of development is how to make life better than today. On the other hand, major changes themselves are not fully achieved. In this case it could be due to the existence of unilateral interests, as the basis of this research is the Law of the Republic of Indonesia Number 26 of 2007 concerning Spatial Planning and the Presidential Regulation of the Republic of Indonesia Number 87 of 2011 concerning Spatial Planning for Batam, Bintan, and Karimun Areas. This research specifically explains how the Effectiveness Legal Theory analizes the implementation of the city spatial regulation. This study uses a socio-legal research. It finds that the settlement arrangement, spatial planning in the Regional Regulation Regarding the Regional Spatial Plan have been in consistent and harmony with the regional regulations concerning the Regional Spatial Plan and the agreement of the community and related offices. However, some of Tanjungpinang's urban space development policies are not in accordance with the policies of the regional regulation.
\end{abstract}

Keywords: Legal Effectiveness, Spatial Planning, Tanjungpinang City.

\begin{abstract}
Abstrak
Pembangunan merupakan upaya sadar yang dilakukan manusia untuk mencapai kehidupan yang lebih baik. Hakekat pembangunan adalah bagaimana agar kehidupan hari depan lebih baik dari hari ini. Di sisi lain, perubahan besar itu sendiri tidak sepenuhnya tercapai. Dalam hal bisa dikarenakan adanya kepentingan sepihak, sebagai landasan penelitian ini adalah Undang-Undang Republik Indonesia Nomor 26 Tahun 2007 Tentang Penataan Ruang, Peraturan Presiden Republik Indonesia Nomor 87 Tahun 2011 Tentang Rencana Tata Ruang Kawasan Batam, Bintan, dan Karimun. Secara khusus penelitian ini hendak menjelaskan bagaimana analisis Teori Efektivitas Hukum terhadap implementasi peraturan daerah tata ruang kota tersebut. Penelitian ini menggunakan metode penelitian hukum empiris. Hasil penelitian menunjukkan bahwa pengaturan permukiman, penataan ruang tersebut tercantum dalam Peraturan Daerah Tentang Rencana Tata Ruang Wilayah sudah terdapat konsistensi dan harmonisasi antara peraturan daerah Tentang Rencana Tata Ruang Wilayah dengan kesepakatan masyarakat dan OPD. Namun, sebagian kebijakan pengembangan ruang kota Tanjungpinang belum sesuai kebijakan dari setiap perda yang dibuat.
\end{abstract}

Kata Kunci : Efektivitas Hukum, Tata Ruang, Kota Tanjungpinang.

*Alamat Korespondensi : dzulgranadiv@yahoo.com 


\title{
A. Latar Belakang Penelitian
}

\begin{abstract}
Pemerintah Daerah Kota Tanjungpinang atau Walikota sebenarnya mempunyai tanggung jawab atas terwujudnya suatu pembangunan didaerahnya melalui program-program pembangunan yang telah direncanakan melalui "MUSREMBANG" daerah kota Tanjungpinang. Rencana Tata Ruang Wilayah Kota Tanjungpinang sudah diatur didalam Peraturan Daerah Nomor 10 Tahun 2014 Tentang Tata Ruang Wilayah Kota Tanjungpinang, dimana RT/RW Kota Tanjungpinang disusun sebagai alat operasionalisasi pelaksanaan pembangunan diwilayah kota Tanjungpinang. Adapun Fungsi Rencana Tata Ruang Wilayah Kota Tanjungpinang sebagai berikut :

- Acuan dalam penyusunan Rencana Pembangunan Jangka Panjang Daerah (RPJPD) dalam Rencana Pembangunan Jangka Menengah Daerah (RPJMD).
\end{abstract}

- Acuan dalam pemanfaatan ruang/pengembangan wilayah kota

- Acuan untuk mewujudkan keseimbangan pembangunan dalam wilayah kota.

- Acuan lokasi investasi dalam wilayah kota yang dilakukan pemerintah, swasta dan masyarakat.

- Pedoman untuk penyusunan rencana rinca tata ruang diwilayah kota.

- Dasar pengendalian pemanfaatan ruang dalam penataan/pembangunan wilayah kota yang meliputi penetapan zonasi, perizinan, pemberian insentif dan disinsentif, serta pengenaan sanksi, dan

- Acuan dalam administrasi pertanahan.

Rencana Tata Ruang Wilayah atau RT/RW kota Tanjungpinang sebagai pedoman dan arahan lokasi investasi pembangunan yang dilaksanakan pemerintah. Penataan ruang adalah suatu sistem proses perencanaan tata ruang, pemanfaatan tata ruang dan pengendalian pemanfaatan ruang

Adapun yang menjadi objek dalam penelitian ini adalah Sistem Jaringan Sumber Daya Air dimana didalamnya mengatur beberapa poin-poin yang menjadi objek dalam pelaksanaan pembangunannya yaitu wilayah sungai, sistem jaringan air besih, sistem pengendali banjir, dan sistem pengamanan abrasi pantai yang telah diatur didalam Rencana Tata Ruang Wilayah Kota Tanjungpinang. Untuk dipahami sebagimana diketahui di kota Tanjungpinang sumber air bersih.yang digunakan untuk kebutuhan sehari-hari digunakan sumber air bersih dari Perusahaan Daerah Air Minum atau disingkat PDAM.

Sumber air bersih dikota Tanjungpinang yang di kelola oleh PDAM tidak selalu berjalan mengalir seperti apa yang diharapkan, akan tetapi tidak jarang aliran air bersih tersebut mengalir dengan baik, adapun aliran pengairan yang berasal dari perusahaan air minum ini selalu mati atau tidak efektiv dalam pengairannya kepada masyarakat, begitu juga dengan masa kepemimpinan Walikota sebelumnya yang dipimpin oleh H. Suryatati A. Manan yang menjabat sebagai Walikota Tanjungpinang selama dua periode yaitu pada 
tahun 2003-2008 dan 2008-2013. Sumber mata air yang dikelola oleh perusahaan air minum daerah bersumberkan pada waduk yang berada di Sungai Pulai, yang terletak di kilometer 18 Kabupaten Bintan Prrovinsi Kepulauan Riau.

Untuk studi kasus yang penulis ambil dikota Tanjungpinang tentang efektivitas hukum jaringan sumber daya air pada Peraturan Nomor 10 Tahun 2014 tentang Rencana Tata Ruang Wilayah Kota Tanjungpinang khususnya sistem jaringan sumber daya air periode 2014-2017.

Dari pembahasan yang dikemukakan diatas efektivitas hukum sangatlah penting untuk menjalankan suatu kebijakan yang telah dibuat dan direncanakan sedemikian rupa, dengan demikian akan timbul kekecewaan masyarakat dikarenakan perencanaan pembangunan tidak terlaksana.

\section{B. Perumusan Masalah}

Dari uraian diatas peneliti merumuskan permasalahan sebagai berikut :

1. Bagaimana pelaksanaan Sistem Jaringan Sumber Daya Air pada Peraturan Daerah Nomor 10 Tahun 2014 Tentang Tata Ruang Wilayah Kota Tanjungpinang Periode 2014 - 2017 ?

2. Apakah yang menjadi kendala dalam pelaksanaan Sistem jaringan sumber daya air pada Rencana Tata Ruang Wilayah Kota Tanjungpinang Periode 2014 - 2017?.

3. Bagaimana solusi Agar Pelaksanaan Sistem Jaringan Sumber Daya Air Pada Rencana Tata Ruang Wilayah Kota Tanjungpinang Periode 2014 2017 Sampai ke Target Tahun 2034 ?

\section{Metode Penelitian}

Dalam efektivitas hukum terhadap realisasi Sistem Jaringan Sumber Daya Air pada Peraturan Daerah Nomor 10 tahun 2014 Tentang Tata Ruang Wilayah Kota Tanjungpinang periode 2014 - 2017.

1. Rancangan Penelitian.

Untuk menjawab permasalahan dalam penelitian ini, peneliti akan melakukan beberapa tahap rancangan penelitian sebagai berikut :

2. Penelitian tentang efektivitas Peraturan Daerah Nomor 10 Tahun 2014 Tentang Tata Ruang Wilayah Kota Tanjungpinang Tahun 2014 - 2034.

3. Penelitian tentang kendala-kendala dalam penerapan Peraturan Daerah Nomor 10 Tahun 2014 Tentang Tata Ruang Wilayah Kota Tanjungpinang 2014 - 2034.

Penelitian tentang solusi terbaik agar Peraturan Daerah tentang tata ruang wilayah dapat berlaku efektif dalam penerapannya hingga selesai tahun programnya. Dalam Penulisan Tesis ini penulis menggunakan penelitian hukum empiris/sosiologis. Karena data yang akan diambil dan diteliti oleh peneliti adalah data yang diperoleh secara langsung dari lapangan yang merupakan data primer. 


\section{Metode Analisis Data}

Metode analisa data yang digunakan dalam penelitian ini adalah menggunakan Metode Pendekatan Kualitatif, yaitu suatu pembahasan yang dilakukan dengan cara memadukan antara penelitian kepustakaan dan penelitian lapangan. Penelitian kepustakaan yang dilakukan adalah membandingkan peraturan-peraturan, ketentua-ketentuan dan buku referensi, serta data yang diperoleh, kemudian dianalisis secara kualitatif yang akan memberikan gambaran menyeluruh tentang aspek hukum yang berhubungan dengan masalah yang akan diteliti. ${ }^{1}$

Dalam penelitian ini analisis data dilakukan terhadap bahan-bahan hukum yang dikumpulkan melalui pemilihan dan penggolongan untuk dibedakan satu sama lain mana-mana yang berhubungan dan akan digunakan sebagai data terhadap masalah hukum yang diteliti. Sesuai dengan pendekatan yang digunakan dalam penelitian ini, maka data akan dikelompokkan terlebih dahulu untuk kemudian diolah dan dianalisis menggunakan teori Efektifitas Hukum Soerjono Soekanto.

Data yang diperoleh dalam penelitian ini dianalisis secara yuridis kualitatif dengan menggunakan metode berfikir deduktif (umum-khusus) yaitu dengan menjabarkan, menafsirkan, dan mengkonstruksikan data yang diperoleh berdasarkan norma-norma atau kaidah-kaidah, teori-teori, pengertianpengertian hukum dan doktrin-doktrin yang ada dalam dokumen. Peraturan perundang-undangan, untuk menjawab masalah yang ada. analisis data dilakukan secara bertahap, sehingga kekurangan data penelitian secepatnya dapat diketahui dan sesegera mungkin dilengkapi dengan melakukan penelitian ulang, guna pengambilan data tambahan untuk melangkapi kekurangan data tersebut.

\section{Hasil Penelitian Dan Pembahasan}

Dalam setiap pembangunan sudah diatur rencana tata ruang wilayah kota di Tanjungpinang yaitu Peraturan Daerah Kota Tanjungpinang Nomor 10 Tahun 2017 Tentang Rencana Tata Ruang Wilayah Kota Tanjungpinang, diatur didalam RT/RW kota Tanjungpinang tetapi belum semuanya terlaksana, tetapi akan tetap dilanjutkan pembangunannya sesuai dengan program yang telah dibuat didalam RT/RW yang menjadi turunannya diatur didalamnya. sudah sejauh mana pelaksaaan pembangunan khususnya sistem jaringan sumber daya air sebagaimana yang telah diatur didalam Peraturan Daerah Nomor 10 Tahun 2014 Tentang Rencana Tata Ruang Wilayah Kota Tanjungpinang.

${ }^{1}$ Amiruddin, Pengantar Metode Penelitian Hukum, Jakarta, PT. Raja Grafindo Persada, 2012, hal.34 


\section{Dasar Hukum Pelaksanaan Sistem Jaringan Sumber Daya Air Pada Peraturan Daerah Nomor 10 Tahun 2014 Tentang Rencana Tata Ruang Wilayah Kota Tanjungpinang Periode 2014-2017.}

Peraturan Daerah (Perda) adalah salah satu peraturan perundang-undangan dalam sistem ketatanegaraan Indonesia. Dalam kaitan ini Perturan Daerah adalah peraturan yang bersifat lokal yang berlaku di daerah tempat produk hukum itu dibentuk yaitu daerah Provinsi, Kabupaten/Kota. Dalam pelaksanaan Sistem Jaringan Sumber Daya Air yang diatur didalam Peraturan Daerah Nomor 10 Tahun 2014 Tetang Rencana Tata Ruang Wilayah Kota Tanjungpinang didasarkan atas turunan hukum yang mengaturnya.

Adapun perlunya suatu dasar hukum dalam mengatur segala sesuatu untuk menjadi pedoman bagi pelaksanaannya sehingga Rencana Tata Ruang Wilayah pada suatu daerah tidak dapat diganggu atau diluar dari apa yang telah diatur didalam pasal-pasal yang mengatur guna tercapainya efektivitas hukum dalam suatu tatanan hukum yang sedang berjalan.

2. Hasil Penelitian Terhadap Pelaksanaan Sistem Jaringan Sumber Daya Air Pada Peraturan Daerah Nomor 10 Tahun 2014 Tentang Tata Ruang Wilayah Kota Tanjungpinang Periode 2014-2017.

Rencana Struktur Ruang Wilayah Kota adalah rencana yang mencakup sistem perkotaan wilayah kota dalam wilayah pelayanannya dan jaringan prasarana wilayah kota yang dikembangkan untuk mengintegrasikan wilayah kota selain untuk melayani kegiatan skala kota, meliputi sistem jaringan transportasi, sistem jaringan energi dan kelistrikan, sistem jaringan telekomunikasi, sistem sumber daya air dan sistem jaringan lainnya, dan Penataan ruang adalah suatu sistem proses perencanaan tata ruang, pemanfaatan ruang, dan pengendalian pemanfaatan ruang

Sebagaimana tercantum dalam Peraturan Daerah (Perda) Kota Tanjungpinang Nomor 10 Tahun 2014 tentang Rencana Tata Ruang Wilayah (RTRW) Kota Tanjungpinang, maka semua perencanaan pembangunan dan pengembangan keruangan yang akan dilakukan di Tanjungpinang wajib mengacu pada perda tersebut. $^{2}$

Pelaksanaan Sistem Jaringan Sumber Daya Air yang telah direncanakan belum banyak perkembangan yang dilaksanakan oleh Pemerintah Kota Tanjungpinang ini dapat dibuktikan dengan hasil yang didapat dari penelitian ini, dimana Pemerintah Kota dalam hal ini adalah Walikota Tanjungpinang lebih menekankan pada sumber daya air bersih, wilayah sungai (WS), sistem pengendali banjir, sistem pengaman abrasi pantai.

Perencanaan tata ruang wilayah menjadi salah satu problematika pada perkembangan Kota dewasa ini, perkembangan kota yang cukup cepat dengan pertumbuhan penduduk yang cukup pesat juga, maka masalah lingkungan menjadi suatu masalah yang cukup urgen dalam pembahasan mengenai keberlanjutan lingkungan untuk masa depan generasi. Perencanaan tata ruang

${ }^{2}$ http//:PerdaKotaTanjungpinang.com 
menjadi hal yang penting maka setiap wilayah Provinsi, Kabupaten/kota harus mempunyai aturan yang akan menjadi pedoman dalam penataan ruang dan menjadi acuan dalam pelaksaanaan pembangunan. Rencana Tata Ruang Wilayah (RTRW) Kota Tanjungpinang diatur dalam Peraturan Daerah Nomor 10 Tahun 2014, dimana turunan dari Undang-undang Nomor 5 Tahun 2001 tentang Pembentukan Kota Tanjungpinang (Lembaran Negara Republik Indonesia Tahun 2001 Nomor 85, Tambahan Lemabaran Negara Republik Indonesia Nomor 4112)

Kota Tanjungpinang adalah salah satu kota sekaligus merupakan ibu kota dari Provinsi Kepulauan Riau, Indonesia. Dengan Koordinat $0^{\circ} 5^{\prime}$ Lintang Utara; $104^{\circ} 27^{\prime}$ Bujur Timur. Provinsi Kepulauan Riau berbatasan dengan Vietnam dan Kamboja di sebelah utara; negara Malaysia dan Provinsi Kalimantan Barat di timur; Provinsi Kepulauan Bangka Belitung dan Jambi di selatan; Negara Singapura, Malaysia, dan Provinsi Riau di sebelah barat.

Untuk melaksanakan suatu pembangunan ataupun perubahan suatu pembangunan hendaknya tidak terlepas dari suatu rencana awal yang telah diatur oleh Walikota bersama Dewan Perwakilan Rakyat Daerah melalui yang namanya Rencana Tata Ruang Wilayah Kota, untuk pembangunan kota Tanjungpinang agar lebih efektif dalam pelaksanaannya telah diatur didalam Peratura Daerah Daerah Nomor 10 tahun 2014 Tentang Rencana Tata Ruang Wilayah Kota Tanjungpinang, sebagaimana diatur didalam Peraturan Presiden Nomor 87 Tahun 2011 Tentang Rencana Tata Ruang Kawasan Batam, Bintan, dan Karimun.

\section{Pelaksanaan Sistem Jaringan Sumber Daya Air Pada Peraturan Daerah Nomor 10 Tahun 2014 Tentang Tata Ruang Wilayah Kota Tanjungpinang Periode 2014-2017.}

Sistem jaringan sumber daya air yang akan dilaksankan dalam pembangunannya meliputi :
a. Wilayah sungai (WS)
b. Sistem Jaringan Air Bersih
c. Sistem Pengendali banjir, dan
d. Sistem pengaman abrasi pantai.

Ketentuan Pengendalian Pemanfaatan Ruang Wilayah Kota adalah ketentuanketentuan yang dibuat/disusun dalam upaya mengendalikan pemanfaatan ruang wilayah kota agar sesuai dengan Rencana Tata Ruang Wilayah kota yang dirupakan dalam bentuk ketentuan umum peraturan zonasi, ketentuan perizinan, ketentuan insentif dan disinsentif, serta arahan sanksi untuk wilayah kota.

Pelaksanaan Sistem Jaringan Sumber Daya Air yang telah direncanakan sudah banyak perkembangan yang dilaksanakan oleh Pemerintah Kota Tanjungpinang ini dapat dibuktikan dengan hasil yang didapat dari penelitian ini, dimana Pemerintah Kota dalam hal ini adalah Walikota Tanjungpinang lebih menekankan pada sumber daya air bersih, wilayah sungai (WS), sistem pengendali banjir, sistem pengaman abrasi pantai. 
Pengembangan sistem sumber daya air sebagaimana dimaksud adalah :

a. Aspek konservasi sumber daya air;

b. Pendayagunaan sumber daya air; dan

c. Pengendalian daya rusak air.

Adapun sisstem jaringan air bersih sebagaimana di rencanakan didalam Peraturan Daerah Nomor 10 Tahun 2014 Tentang Tata Ruang Wialayah Kota Tanjungpinang adalah pembangunan sistem jaringan air bersih untuk jangka pendek sampai jangka menengah, dan sisitem jaringan air bersih untuk jangka panjang. Untuk pengembangan sistem jaringan air bersih untuk jangka pendek sampai jangka menengah dilakukan melalui :

a. Mempertahankan pelayanan waduk sungai pulai dengan memperkuat inteke sungai Gesek dan interkoneksi waduk Galang Batang.

b. Pemanfaatan kolong-kolong atau lobang bekas tambang dan tampungan lainnya sebagai sumber air baku, dan

c. Pemanfaatan air laut sebagai air baku untuk minum.

Untuk pengembangan sistem jaringan air bersih dan sumber air baku untuk melayaani kota Tanjungpinang untuk jangka panjang yaitu dilakukan melalui pembangunan Estuari DAM muara Sungai Dompak.

Dalam pengendalian banjir Pemerintah kota Tanjungpinang dalam perencanaannya seperti yang sudah direncanakan didalam Perda yaitu dilakukan melalui sistm polder yang terletak di Kecamatan Bukit Bestari. Sedangkan sistem pengamanan abrasi pantai dilakukan dengan pembangunan tebing pengaman dan / atau konstruksi beton di sepanjang pantai Pulau Penyengat, Pantai Senggarang Besar, Pantai Barat Tanjungpinang, Pantai Pulau Dompak, dan Pantai Dompak Seberang sampai Tanjung Mocoh.

Adapun dalam pembahasan penelitian ini peneliti memberikan batasan dalam pelaksanaan Peraturan Daerah Nomor 10 Tahun 2014 Tentang Rencana Tata Ruang Wilayah Kota Tanjugpinang Tahun 2014-2034 yaitu hanya pada periode 2014 sampai 2017 yaitu selama kurun waktu pemerintahan Walikota selama tiga tahun dan pokok bahasan yang dibahas didalam Peraturan Daerah tersebut hanya pasal yang mengatur Sistem Jaringan Sumber Daya Air. Sehingga dalam penelitian ini peneliti berkesimpulan bahwasanya untuk hasil penelitin yang telah berjalan terhitung dari tahun 2014 sampai 2017 memberikan penilaian sebanyak lima belas persen jika peraturan daerah Nomor 10 Tahun 2014 Tentang Rencana Tata Ruang Wilayah Kota Tanjungpinang dapat terealisasi sesuai dengann tujuan dari pembangunan yang telah di atur sehingga dapat dikatakan bahwa telah efektif suatu hukum tersebut yaitu peraturan daerah Nomor 10 Tahun 2014 Tentang Rencana Tata Ruang Wilayah Kota Tanjungpinang.

Didalam pelaksanaannya, kenapa dalam penelitian ini peneliti tidak memberikan penilaian seratus persen, ini dikarenakan jika peneliti menganalisis penelitian ini sampai akhir periode yaitu dari tahun 2014 hingga 2034 baru dapat dikatakan pelaksanaan pembangunan yang telah diatur didalam Peraturan Daerah Nomor 10 Tahun 2014 Tentang Rencana Tata 
Ruang Wilayah Kota Tanjungpinang tahun 2014-2034 berarti masa kerjanya selama dua puluh tahun itu berhasil terlaksana semua seperti apa yang telah direncanakan.

Pelaksanaan Sistem Jaringan Sumber Daya Air yang telah direncanakan sudah banyak perkembangan yang dilaksanakan oleh Pemerintah Kota Tanjungpinang ini dapat dibuktikan dengan hasil yang didapat dari penelitian ini, dimana Pemerintah Kota dalam hal ini adalah Walikota Tanjungpinang lebih menekankan pada sumber daya air bersih, wilayah sungai (WS), sistem pengendali banjir, sistem pengaman abrasi pantai.

Pada hakikatnya keberlanjutan pelaksanaan pembangunan yang telah diatur dan direncanakaan didalam Peraturan Daerah Nomor 10 Tahun 2014 Tentang Tata Ruang Wilayah Kota Tanjungpinan Tahun 2014-234 jikaa tidak ada perubahan dan kendala dalam pelaksanaanya terus berlanjut hingga sampai ke target pencapaiannya yaitu tahun 2034 kedepan.

Namun untuk merealisasikan Peraturan Daerah Nomor 10 Tahun 2014 Tentang Rencana Tata Ruang Wilayah Kota Tanjungpinang Tahun 20142034, ini memang mempunyai jangka waktu yang sangat panjang dimana dalam pelaksanaannya membutuhkan banyak biaya anggaran yang dikeluarkan namun pada hakikatnya apapunyang terjadi pemeriintah khusunya pemerintah kota harus dapat bertanggung jawab atas segala resiko yang dihadapi.

Sebagaimana dikatakan oleh seorang anggota dewan yang telah melakukan wawancara terdahulu, Pemerintah Daerah dalam membuat atau merencanakan suatu Peraturan Daerah Tentang Rencana Tata Ruang Wilayah, ini harus berkoordinasi dengan Pemerintah Provinsi setelah mendapatkan laporanlaporan melalui Musrembang.

Jadi dalam hal ini antara Rencana Tata Ruang Wilayah kabupaten/kota itu terkoneksi dengan Rencana Tata Ruang Wilayah Provinsi dan Rencana Tata Ruang Wialayah Provinsi terkoneksi dengan Pusat, jadi disini akan terjadi saling keterikatan antara satu dengan yang lainnya dan akan terjadi sinkronisasi dalam pelaksanaan pembangunan sesaui dengan Rencana Tata Ruang Wilayah yang telah di buat oleh masing-masing daerah.

Adapun beberapa pelaksanaan didalam merealisasikan rencana yang telah diatur didalam Peraturan Daerahh Nomor 10 Tahun 2014 Tentang Rencana Tata Ruang Wilayah kota Tanjungpinang yang dijumpai peneliti diwaktu wawancara dengan beberapa nara sumber adaa yang mengatakan bahwasanya belum sepenuh Pemerintah Kota dapat melaksanakan atau merealisasikan apa yang menjadi rencana didalam perda tersebut memang ini wajar-wajar saja tidak setiap daerah didalam pelaksanaan tidak mengalami kekurangankekurangan didalam pelaksanaan. Apalagi daerah hanya sifatnya menerima apa yang yang diberikan dari pusat saja, itupun tergantung dari anggaran yang ada.

Namun daripada itu pelaksanaan pembangunan akan terus dijalankan dengan jalan pemerintah dapat memberikan atau menyerahkan kepada pusat apa-apa 
saja yang menjadi prioritas di daerah guna kepentingan masyarakat apapun itu kebutuhannya pusat wajib memberikan bantuan didalam pelaksanaannya. Dalam hal seperti ini wajar-wajar saja dilakukan oleh pihak pemerintah daerah dalam hal ini pemerintah kota kepada pemerintah pusat, ini dikarenakan semua anggaran belanja daerah berasal dari peemerintah pusat, kalau yang namanya Pendapatan Asli Daerah itu baru asli anggaran dari daerah.

4. Kendala dan Hambatan Terhadap Pelaksanaan Sistem Jaringan Sumber Daya Air Pada Peraturan Daerah Nomor 10 Tahun 2014 Tentang Tata Ruang Wilayah Kota Tanjungpinang Periode 2014-2017.

Dalam Pelaksanaan suatu rencana apapun itu selalu tidak seperti apa yang telah direncanakan dikarenakan selalu ada kendala dan hambatan yang timbul dalam pelaksanaannya apakah itu kendala dan hambatan yang datang dari faktor alam atau kendala dan hambatan yang datang dari manusia itu sendiri, namun dengan demikian hendaklah hambatan dan kendala yang timbul bukan menjadi suatu halangan atau rintangan dalam pelaksanaannya, semua ada jalan keluarnya baik itu secaran kekeluargaan maupun secara hukum.

Adanya beberapa faktor yang menjadi kendala dalam pelakssanaan Peraturan Daerah dimana Peraturan Daerah merupakan turunan dari peraturan perundang-undangan yang harus ditaati dan dijalankan sesuai dengan apa yang telah diatur didalamnya, namun dalam pelaksanaannya dilapangan tetap masih ada individu atau sekelompok orang yang tidak mentaatinya, sehingga bisa dikatakan suatu hukum itu tidak efaktif dalam menjalankannya atau ada yang baik sengaja maupun tidak disengaja. Dalam hal ini Peraturan Daerah yang mengatur yang tentang rencana tata rung wilayah dimana pertumbuhan dan perkembangan baik masyarakat maupun wilayah itu dapat mempengaruhi jalannya suatu peraturan daerah yang mengatur rencana tata ruang.

Sebagai contoh kendala dan hambatan yang datangnya dari alam misal nya untuk pelaksanaan sistem jaringan sumber daya air yang benar-benar terlaksana sesuai dengan apa yang direncanakan dalam pembangunan untuk pananganan abrasi pantai dengan melakukan reboisasi hutan bakau disetiap pantai yang rawan dengan datangnya arus gelombang laut yang besar, maka untuk melakukan penanamannya lima puluh meter ke arah laut atau lepas pantai, namun jika ditanamkan pohon bakau tersebut maka pohon bakau akan mati atau tidak mau hidup, jadi pelaksanaan penanaman pohon bakau terkendala atau tidak terlaksana dengan baik, demikian dikatakan Bapak Hari salah seorang petugas dari BP. DAS kota Tanjungpinang Kepulauan Riau.

Kendala dan hambatan yang disebabkan dari faktor alam adalah keadaan geografis dikota Tanjungpinang, misalkan didalam pelaksanaan pembangunan drainase sebagai aliran air buangan air hujan dimana mendapat kesulitan dalam pengerjaannya dikarenakan lokasi lahan yang rawan erosi dan akan selalu terjadi longsor, yang datangnya dari faktor manusia itu sendiri seperti pihak-pihak pengembang jika dalam pelaksanaan pembangunan wilayah pemukiman selain tidak memperdulkan lahan dan lokasi sebagai tempat untuk membangun perumahan tersebut, apakah itu termasuk kedalam zona kawasan 
lindung ataukah masih didalam zonasi terbuka hijau ataukah pengairan pembuangan aliran perumahan para pengembang atau developer tidak menghiraukannya.

Kemudian juga telah menjamurnya penduduk dikota Tanjungpinang, maka dengan adanya hal yang demikian itu otomatis pembangunan perumahan sebagai tempat pemukiman penduduk kota Tanjungpinang, kenapa ini dapat dikatakan sebagai hambatan dalam pelaksanaan pembangunan yang sesuai dengan Rencana Tata Ruang Wilayah, dikarenakan didalam RTRW yang sudah dibuat yang mana didalamnya diatur zonasi sebagai kawasan hijau terbuka namun setelah terjadinya kepadatan penduduk maka dimana yang tadinya diatur sebagai kawasan hijau dialih fungsikan menjadi lokasi pemukiman penduduk kota Tanjungpinang.

Ada empat kategori perbuatan yang menyebabkan timbulnya kerusakan hutan. Diantaranya yaitu :

1. Kerusakan hutan dapat terjadi akibat perbuatan karena kesengajaan subyek hukum meliputi, manusia dan atau badan hukum.

2. Kerusakan hutan dapat terjadi akibat perbuatan karna kelalaian subyek hukum meliputi, manusia dan atau badan hukum.

3. Kerusakan hutan dapat terjadi karena ternak dan daya-daya alam (misalnya, gempa bumi, letusan gunung, banjir, dan sebagainya)

4. Kerusakan hutan dapat terjadi karena serangan Hama dan penyakit pohon ${ }^{3}$

Perkembangan penduduk dan Pemekaran wilayah bisa saja menjadi salah satu penyebab kendala dari realisasinya pelaksanaan sistem jaringan sumberdaya air ini dikarenakan bisa terjadi tumpang tindih dalam pelaksanaannya, misalkan salah satu penyebab yang menjadi kendala dalam pelaksanaan Sistem Jaringan Sumber Daya Air, Kendala lain yang akan mengakibatkan tidak terlakssananya Peraturan Daerah yang mengatur Sistem jaringan sumber daya air adalah adanya beberapa kepentingan baik itu kepentingan individu maupun kepentingan sosial. Ini sulit untuk dihindarkan dari permasalahan ini apalagi menyangkut soal kepentingan sekelompok orang yang serba salah bila tidak dikuti.

Kemudian yang menjadi faktor kendala dalam pelaksanaan Peraaturan Daerah Nomor 10 Tahun 2014 Tentang Rencana Tata Ruang Wilayah Kota Tanjungpinang Tahun 2014-20134 periode 2014-2017 adalah kurangnya anggaran daerah, sehingga pelaksanaan kegiatan tidak dapat teratasi secara menyeluruh dan kelanjutan pelaksanaannya akan dilaksanakan tahun berikutnya. Jika setiap tahunnya terjadi seperti ini maka pelaksanaan Sistem jaringan Air bersih sulit untuk dilaksanakan secara otomatis efektivitas hukum dari Peraturan Daerah tersebut tidak bisa terealisasi.

Kendala lain yang timbul dari pelaksanaan dilapangan dalam merealisasikan Peraturan Daerah Nomor 10 Tahun 2014 Tentang Tata Ruang Wilayah Kota Tanjungpinang khususnya untuk sistem jaringan sumber daya air bersih

${ }^{3}$ Alam Setya.Hukum Lingkungan Konservasi Hutan , PT Rineka Cipta, Jakarta , 1997, Hlm.5 
hingga sampai ke target yang telah tetapkan yaitu dari tahun 2014 hingga 2034, adanya pergantian pemimpin dalam hal ini adalah Walikota, kenapa demikian ini dikarenakan jika pemimpin diganti berarti semua kebijakan yang telah diatur dan disusun secara otomatis juga akan dirubah.

\section{E. Kesimpulan}

Adapun kesimpulan dalam penelitian ini adalah sebagai berikut :

Pelaksanaan Sistem Jaringan Sumber Daya Air pada Peraturan Daerah Nomor 10 Tahun 2014 Tentang Tata Ruang Wilayah Kota Tanjungpinang Periode 2014-2017 dinilai sudah berjalan efektif yakni oleh Pemerintah Kota Tanjungpinang ini dapat dibuktikan dengan hasil yang didapat dilapangan melalaui observasi baik itu melalui wawancara secara langsung dengan Anggota Dewan Permusyawaratan Daerah maupun kepada masyarakat selaku pengguna jasa yang ada di penelitian ini, dimana Pemerintah Kota dalam hal ini adalah Walikota Tanjungpinang lebih menekankan pada sumber daya air bersih, wilayah sungai (WS), sistem pengendali banjir, sistem pengaman abrasi pantai. Sehingga masyarakat Kota Tanjung Pinang secara langsung telah menikmati dari implementasi nyata terhadap peraturan daerah tersebut.

1. Kendala yang ditemukan oleh Penulis dalam melakukan penelitian ini guna tercapainya pelaksanaan sistem jaringan sumber daya air pada Peraturan Daerah Nomor 10 Tahun 2014 Tentang Tata Ruang Wilayah Kota Tanjungpinang Periode 2014-2017 adalah dari faktor alam dan hambatan yang datang dari manusia itu sendiri atau biasa disebut human error, namun dengan demikian hendaklah hambatan dan kendala yang timbul bukan menjadi suatu halangan atau rintangan dalam pelaksanaannya, semua ada jalan keluarnya baik itu secara kekeluargaan maupun secara hukum.

2. Solusi sistem jaringan sumber daya air pada Peraturan Daerah Nomor 10 Tahun 2014 Tentang Tata Ruang Wilayah Kota Tanjungpinang Periode 2014-2017 agar pelaksanaan sistem jaringan sumber Sampai ke Target Tahun 2034 adalah tergantung dengan komitmen dan konsistensi pemerintah Kota Tanjung Pinang dalam menyikapi peraturan dan realisasi yang telah berjalan dengan baik sampai ke target yang telah ditentukan, peran aktif masyarakat Kota Tanjung Pinang juga berpengaruh penting terhadap tercapainya Kota Tanjung Pinang sebagai Kota dengan pelayanan yang prima. Diharapkan stake holders dalam hal ini yaitu pemerintah kota Tanjung Pinang lebih peka terhadap keluhan masyarakat dengan meningkatkan MUSREMBANG guna terpenuhinya kesejahteraan masyarakat Kota Tanjung Pinang sesuai dengan Peraturan Daerah Nomor 10 Tahun 2014 Tentang Tata Ruang Wilayah Kota Tanjungpinang Periode 2014-2034. 


\section{DAFTAR PUSTAKA}

\section{Buku}

Ahmad Ali, dan Wiwie Heryani, Menjelajahi Kajian Empiris Terhadap Hukum, Jakarta, Kencana Prenada Media Group, 2013.

Ahmad Rifai, Penemuan Hukum Oleh Hakim Dalam Persepektif Hukum Progresif, Jakarta, Sinar Grafika, 2014.

Amiruddin, Pengantar Metode Penelitian Hukum, Jakarta, PT. Raja Grafindo Persada, 2013.

Anil Dawan, "Keadilan Sosial : Teori Keadilan Menurut John Rawls dan Implementasinya Bagi Perwujudan Keadilan Sosial di Indonesia

Asep Warlan Yusuf, Pranata Pembangunan, Bandung, Universitas Parahiyangan, 1997.

Bagir Manan, Politik Hukum Otonomi Sepanjang Peraturan Perundangundangan Pemerintah daerah, Jakarta, Pustaka Sinar Harapan, 1996.

Barda Arief Nawawi, Kapita Selekta Hukum Pidana, Cetakan Ketiga, Bandung, Citra Aditya, 2013.

Budi Winarno, Etika Pembangunan, Jakarta, CAPS, 2013.

BS Muljana, Perencanaan Pembangunan Nasional, Proses Penyusunan Rencana Pembangunan Nasional dengan Fokus Repelita V, UI-Press. Bandung, 2001.

D.A Tiasnaadmidjaja dalam Asep Warlan Yusuf, Pranata Pembangunan, Bandung, Universitas Parahiyangan, 1997.

Darmawan Triwibowo dan Sugeng Bahagijo, Mimpi Negara Kesejahteraan. Jakarta, Pustaka LP3ES Indonesia, 2006

G Esping-Andersen, Social Foundation for Postindustrial Economies, Oxford : Oxford University Press. 20, sebagaimana dikutip dari Darmawan Triwibowo dan Sugeng Bahagijo. Mimpi Negara Kesejahteraan. Jakarta : Pustaka LP3ES Indonesia, 2006.

Herman Hermit, Pembahasan Undang-Undang Penataan Ruang, Bandung, Mandar Maju, 2008.

Hans Kung dalam Budi Winarno, Etika Pembangunan, Yogyakarta, CAPS, 2013.

Ida Zuraida, Teknik Penyusunan Peraturan Daerah, Jakrta, Sinar Grafika, 2013.

H.S Salim dan Erlis Septiana Nurbani, Penerapan Teori Hukum Pada Tesis dan Disertasi, 2013, Rajawali Press, 2013. 
J. Kaloh, Kepemimpinan Kepala Daerah, Jakarta, Sinar Grafika, 2009.

John Rawls. "A Theory of Justice", Havard University Press, Cambridge, Massachusetts, 1995, yang diterjemahkan oleh Uzair Fauzan dan Heru Prasetyo, Teori Keadilan : Dasar-Dasar Filsafat Politik Untuk Mewujudkan Kesejateraan Sosial dalam Negara. Yogyakarta : Pustaka Pelajar, 2006.

John Rawls, Theory of Justice. London : Oxford University Press, 1973, sebagaimana dikutip dari Damanhuri Fattah, "Teori Keadilan Menurut John Rawls", Jurnal TAPIs, Vol. 9, No. 2 Juli-Desember 2013.

Lilik Mulyadi, “Teori Hukum Pembangunan Prof. Dr. Mochtar Kusumaatmadja, S.H., LL.M : Sebuah Kajian Deskriptis Analitis

MA Budiono, Kamus Lengkap Bahasa Indonesia, Surabaya, Karya Agung, 2015.

Mochtar Kusumaaatmadja, Teori Hukum Pembangunan, Jakarta, HuMa, 2012.

Moh. Mahfud MD, Hukum dan Pilar-Pilar Demokrasi, Yogyakarta : Gama Media, 1999.

Pasolong Harbani, Kepemimpinan Birokrasi, Bandung, Alfabeta, 2010.

Rangga Wijaya Rosidi, Pengantar Ilmu Perundang-undangan Indonesia, Bandung, Mandar Maju, 1998.

Sedarmayanti, 2012, Good Governance \& Good Corporate Governance, Mandar Maju, Bandung

Soerjono Seokamto, Efektivitas Hukum dan Peranan Saksi, Bandung, Remaja Karya, 1985.

Ihza Mahendra, Yusril, dkk, 1997, Hukum Dan Pembangunan, Badan Pendidikan dan Pelatihan Departemen Dalam Negeri, Jakarta.

Nawi, Syahruddin, 2014, Pengantar Sosiologi Hukum, Fharras Jaya Grafika, Makasar.

Shidarta dalam Lilik Mulyadi, "Teori Hukum Pembangunan Prof. Dr. Mochtar Kusumaatmadja, S.H., LL.M : Sebuah Kajian Deskriptis Analitis"

Satjipto Raharjo, 2012 Ilmu Hukum, PT. Citra Aditya Bakti, , Cet ke 7

Syamsul Arifin, Leadership Ilmu dan Seni Kepemimpinan, Jakarta, Mitra Waeana Media, 2012

Sudding, Syarifuddin, 2014, Perselingkuhan Hukum dan Politik Dalam Negara Demokrasi, Rangking Education dan Republik Institute, Yogyakarta 
Yos Johan Utama, 2008, Membangun Peradilan Tata Usaha Negara yang Berwibawa, Naskah Pidato Pengukuhan Guru Besar dalam Ilmu Hukum, Universitas Diponegoro, Semarang. 2008.

Yusril Ihza Mahendra, dkk, Hukum Dan Pembangunan, Jakarta, Badan Pendidikan dan Pelatihan Departemen Dalam Negeri, 1997.

\section{Internet}

http://badilum.info/upload_file/img/article/doc/kajian_deskriptif_analitis_teori_hu kum_pembangunan.pdf

http://shidarta-articles.blogspot.co.id/2012/05/teori-hukum-integratif-dalamkonstelasi.html

http://badilum.info/upload_file/img/article/doc/kajian_deskriptif_analitis_teori_hu kum_pembangunan.pdf

http://download.portalgaruda.org/article.php?article $=161102 \& \mathrm{val}=5897 \&$ title $=\mathrm{TE}$ ORI\%20KEADI\%20LAN\%20MENURUT\%20JOHN\%20RAWLS

\section{Peraturan Perundang-Undangan}

Undang-Undang Nomor 26 Tahun 2007 Tentang Penataan Ruang Wilayah.

Undang-Undang Nomor 12 Tahun 2011Tentang Pembentukan Peraturan Perundangundangan

Peraturan Menteri Dalam Negeri Nomor 80 Tahun 2015 Tentang Pembentukan Produk Hukum (Berita Negara Republik Indonesia Tahun 2014 Nomor 2036) 